folk/ed. Derg, 2020; 26(2):393-408

DOI: $10.22559 /$ folklor.1097

\title{
Hollandalı Göçmen Yazar Murat Işık'tan Bir Göç ve Kültürlenme Romanı: Verloren Grond (Kayıp Toprak)
}

\author{
A Migration and Acculturation Novel from the Dutch \\ Immigrant Author Murat Işık: Verloren Grond (Lost Ground)
}

Nazlı Gündüz*

\begin{abstract}
Öz
Eski çağlardan günümüze açlık, kuraklık, husumet ya da daha iyi eğitim aray1Şı insanın yaşadığı toprakları bırakıp aynı topraklarda başka yerlere veya başka memleketlere gitmesine neden olmuştur ve halen de olmaktadır. Bu tür olaylar, kaçınılmaz olarak kültür olgusunu ön plana çıkarır. Göç olgusu birçok yazar tarafından ele alınmış ve eserlerinin ana teması yapılmıştır. Bu makalede, küçük yaşta göçe tanıklık etmiş olan Zaza/Alevi asıllı Hollandalı yazar Murat Işık'ın kaleme aldığ 1 ve ailesinin gerçek yaşam öyküsünden izler taşıyan Verloren Grond (Kayıp Toprak) romanında iç göç etmenlerini ne şekilde ele aldığı incelenmiştir. Eserde bir köyden başka bir köye ve oradan da büyük şehre göç eden Uslu ailesinin önce zorunlu, sonra gönüllü göç edişi, aile bireylerinin duygu, düşünce, umut ve hayal kırıklıkları eşliğinde gündeme getirilir. Eser, göç kuramı itme-çekme modeli ve göç üzerine oluşturulan birtakım itici ve çekici etmenler aracılığı ile irdelenir. Bireyler yaşadıkları yerlerden belirli itici nedenlerden dolayı ayrılarak kendilerini çekici etmenlerin beklediğini düşündükleri yerlere giderler. Eserde en önemli itici etmen
\end{abstract}

Geliş tarihi (Received): 19.10.2019 - Kabul tarihi (Accepted): 11.02.2020

* Dr. Öğr. Üyesi, Ankara Hacı Bayram Veli Üniversitesi, Edebiyat Fakültesi, İngiliz Dili ve Edebiyatı Bölümü. nazli.gunduz@hbv.edu.tr. ORCID ID: 0000-0001-8728-0372. 
aile reisinin bacağının kesilmesi ve buna karşılık ailenin ekonomik kurtuluşu için çekici etmen teşkil eden kendi köyünde bulunan babadan kalma tarladır. Toprak olgusu insanoğlu için önemlidir çünkü ata mirasıdır, aidiyeti, kimliği ve özgürlügüü ifade eder. İkinci önemli itici etmen deprem ise çekici etmen olarak büyük şehre gitme fikrini doğurur. Göçlerin ardından farklı sosyal, kültürel ve psikolojik uyum sorunları yaşayan aile bireyleri kültürlenme süreciyle karşı karşıya kalır. Göç olgusu Uslu ailesi için ekonomik, kültürel ve toplumsal açıdan önem taşır ve neticesinde her bir birey için olumlu ve olumsuz sonuçlar doğurur.

Anahtar sözcükler: iç göç, toprak, edebiyat ve göç, kültürlenme, itici etmenler, çekici etmenler

\begin{abstract}
Since ancient times, hunger, drought, animosity or the search for better education caused people to leave their lands and go to other places or other countries. Inevitably, these types of moves bring the phenomenon of culture to the fore. This article discusses how the Zaza /Alevi born Dutch writer Murat Işık, who witnessed emigration from Turkey to The Netherlands, deals with the factors of internal migration in his novel Verloren Grond (Lost Ground), which bears traces of his family's biography. In the work, migration of the Uslu family brings to the agenda feelings, hopes and disappointments of family members. The novel is examined with the aid of both the push-pull model of migration and pushing and pulling factors leading to migration. The most important pushing factor in the novel is the father's leg amputation. The ground inherited from his father is thought to be the only pulling factor for the family because it will provide them with economic salvation. The phenomenon of land is very important for human beings because it represents ancestral heritage, belongingness, identity and freedom. The second important pushing factor is an earthquake, which triggers the idea of going to the big city as a pulling factor. After the migrations, the members of the family experience various types of social and cultural adaptation problems. Thus, through the novel we realize that the phenomena of migration are economically, socially and culturally important for the Uslu family, and consequently have positive and negative results for each individual.
\end{abstract}

Keywords: internal migration, land, literature and migration, acculturation, factors of migration

\title{
Giriş
}

Hollanda gazetesi Volkskrant'a ${ }^{1}$ verdiği demeç ve bir televizyon programında yaptığ söyleşide öz yaşam öyküsünü anlatan Hollandalı yazar Murat Işık, Zaza Alevi’si ailesinin önce Türkiye'nin doğusunda bulunan Muş ilinin Varto ilçesinden, büyük şehir İzmir'e, oradan da önce Almanya, sonra Hollanda'ya göç ettiğini dile getirir (Parmando 24Culture, 2015; Vuijsje, 2018: 1). 1977'de İzmir'de doğan Işık, beş yaşında babasının kararı ile ailecek göç ettikleri Amsterdam'da büyür, Amsterdam Üniversitesi ve San Francisco Devlet Üniversitesinde hukuk okur ve avukat olur. Hollanda'da doğmamış olsa bile, bu ülkede okula gidip bu ülkenin kültürü ile yoğrulduğu için kendini Hollandalı hissetmekte ve görmektedir. Genlerinde 
taşıdığı hikâye anlatıcı (dengbej) miras onu yazar olmaya teşvik eder ve avukatlık mesleğini icra ederken bir yandan da Hollanda dilinde öyküler yazar. 2011 yılında Hollanda'da düzenlenen bir öykü yarışmasında ailenin İzmir'e duyduğu hasreti anlatan De Purpuren Citroen (Mor Limon), daha sonra 2012'de De Laatste Reis (Son Yolculuk) adlı öyküleri ile edebiyat ödülleri alır. İlk romanı Verloren Grond (2012) (Kayıp Toprak, 2014) Hollanda ve Belçika' da en iyi çıkış yapan roman ödülü olan Bronz Baykuş Halk Ödülü’nü alır. Yine Hollanda dilinde yazdığı ikinci romanı Wees Onzichtbaar² (Görünmez Ol) ile 2017 yılında en çok satanlar listesinde yer alarak kitabevleri ödülüne hak kazanır. 2018 y1lında Libris edebiyat ödülü ile taçlandırılır ve ödülünü Hollanda kültür bakanı Ingrid Engelshoven'ın elinden alır (Becker, 2018). Yazar bu ödülle hem 50.000 Avro, hem de onurunu geri kazandığını düşünür. Çünkü lisede yabancı kökenli olduğu ve vasıfsız göçmenlerin çoğunlukla temizlik işlerinde çalıştığ1 için bazı sınıf arkadaşları tarafından önyargılı bir şekilde 'temizlikçi' lakabı ile aşağılanmıştır ancak bu ödülle her Türk'ün temizlikçi olmadığını göstermiştir. Işık, Amsterdam'da çıkarılan Het Parool gazetesine verdiği demeçte aldığ ödüller ile kendini Hollanda halkına kabul ettirdiğini ve başarısının “tatlı zaferini” kutladığını gündeme getirir (Wiegman, 2018:1). Her iki romanında Işık ailesinin öz yaşam öyküsünden kesitleri kurgu ile harmanlar ve Hollanda halkına sadece sosyokültürel çalışmalarda ve gazete sütunlarında karşılaşabilecekleri ötekinin yaşantısını tanıtır. Edward Said'in öne sürdüğü oryantalist bakış açısında kendini üstün gören Batılının gözünde Doğulu gelişmemiş ve geri kalmış ötekidir (2006: 11). Önceki yüzyıllarda Türkiye topraklarını ziyaret eden Batılı gezginler; "Gezdikleri yerlerin ve kültürlerin kendilerininkinden farklı olduğunu göz ardı ederek, bu toplumları kendi değerleriyle yargılamaya ve yalan yanlış bilgileri Batılı toplumlara aktarmış" ve kalıplaşmış değerler oluşmasına neden olmuştur (Gürsoy, 2007: 298). İnsanın varoluş sorununu temsil eden yazınsal ifade yazarımızın iç dünyasını dışa vurmasına katkı sağlamıştır (Ataseven, 2015: 59).

1966'da meydana gelen yıkıcı bir depremin ardından Varto'dan göç edip İzmir'e yerleşen aile, babanın siyasi görüşleri nedeniyle önce Almanya'ya oradan da Hollanda'ya göç eder ve göçmenlerin yaşadığı bir mahalleye yerleşir. Göçmen ülkede işçi sınıfına dâhil olmak istemeyen baba restoran açar fakat başarılı olamaz ve sosyal yardım almak zorunda kalır. Kocasından yeterli maddi destek görmeyen anne, ekonomik özgürlüğünü elde etmek için çalışmaya başlar. Baba oğlunun okuyup iyi mevkilere gelmesini ister ve iyi okullarda okumasının mücadelesini verir. Murat Işık Volkskrant'a (Halk gazetesi) verdiği bir röportajında; "Babam veli toplantısında sesini yükseltmeseydi beni hak ettiğim VWO (Bir çeşit Fen/ Sosyal Bilimler Lisesi) yerine düz liseye göndereceklerdi ve belki üniversite okumayacaktım” der (Vuijsje, 2018: 1). Okulda bazı sınıf arkadaşlarından gördüğü dışlanma ve aşağılayıcı ifadeler nedeniyle içine kapanır ama yılmaz çünkü onun var olabilmesi ve kendini ispatlaması için tek yapabileceğinin okulunda başarılı olup iyi bir meslek edinmek olduğunun bilincindedir (Vuijsje, 2018: 1). İçinde büyüdüğü toplumu iyi gözlemler ve ilkokul öğretmeninin teşviki ile üye olduğu halk kütüphanesinde kitaplarla tanışır. Çok okur ve dilini geliştirir, içinde yaşadığı kültür ile bütünleşir ve yıllar geçtikçe kendini o kültüre daha yakın bulur ve asimile olur. Yazılarını Hollanda dilinde yazar çünkü okuma-yazmayı bu dilde öğrenmiştir ve kendini en iyi bu dilde ifade eder.

Bu çalışmada, birçok romana konu olan iç göç, göçmen yazar Murat Işı1k’ın Hollandaca yazdığı Verloren Grond ( 2012) eserinin aslı ${ }^{3}$ ile Türkçeye yapılan çevirisi Kayıp Toprak (2014) karşılaştırılarak Lee ve (1966) Piche’nin (2013) göç üzerine oluşturdukları itme-çek- 
me kuramı ve itici- çekici etmenler eşliğinde değerlendirilecektir. Eser, daha iyi yaşam koşulları sağlamak için göç eden bir ailenin kırsal alandan, bir başka kırsal alana, oradan da büyük şehir İzmir'e göç edişine ve bu göçlerin beraberinde getirdiği sorunları gözler önüne serer. Es ve Ateş, (2010: 211); "Kır-kır, kır-kent yönünde ortaya çıkan iç göçler içerisinde kırsal alandan kente göç, kültürel, toplumsal ve ekonomik anlamda değişmeyi süratlendiren ve sonuçları itibariyle olumlu ve olumsuz sonuçlara neden olan bir olgudur" demektedir.

\section{Göç, kültürlenme ve kimlik}

Göç olgusu insanlık tarihi kadar eskidir. İnsanlar memleketlerini ekonomik, siyasi, toplumsal ve eğitim gibi nedenlerden dolayı bırakıp daha iyi şartlar sunan yerlere doğru geçici ya da sürekli olmak üzere göç ederler (Piche, 2013: 8). Bir ülkenin sınırları içinde bulunulan ortamdan başka bir ortama gidip yerleşme eylemine iç göç, başka bir ülkeye giderek oraya yerleşme eylemine ise $d \iota s ̧$ göç denir. Teknolojik gelişmeler nedeniyle gitgide küçülen ve küreselleşen dünyada göç olgusunun iki temel tetikleyicisi vardır. İlki neden sorusu üzerine odaklanır. İnsanları göçe iten temel neden nedir? İkincisi ise yapılan bu göçün amacına ulaşıp ulaşmadığıdır. Araştırmacılar bu sorulardan yola çıkılarak göç kuramları oluştururlar. Lee'nin A Theory of Migration (Göç Teorisi) adlı çalışmasında ortaya attığı itme-çekme kuramından yola çıkılarak göçün neden ve nasıl başlatıldığı incelenebilir (1996: 47). Göç sürecinin başlamasına neden olan, gidilmek istenilen yerler ile ilgili etmenler dörde ayrılır: (1) Bulunulan yer ile ilgili etmenler, (2) göç edilecek yer ile ilgi etmenler, (3) ara etmenler ve (4) bireysel etmenler. Piche ise göçü başlatan etmenleri itici ve çekici olmak üzere ikiye ayırır. (2013: 21). İtici etmenler, göçe neden olan olumsuz koşullar arasında yetersiz yeraltı kaynaklarından, zorlu iklim koşullarına, işsizlikten, eğitim kurumlarının eksikliği gibi birçok olumsuzluğu kapsamaktadır. Çekici etmenler ise, insanları göç etmeye yönlendiren iş imkânlarının çokluğu, sosyal etkinlik alanlarının ve iyi eğitim kurumlarının olması gibi siralanabilir (Y1lmaz, 2011: 222).

Göç sürecinin ardından kültürlenme süreci başlar. Berry, bu süreci bütünleşme, ayrışma, asimilasyon ve marjinalleşme olarak dörde ayırır (1997: 5). Örneklendirmek gerekirse, sosyalleşmenin sonucunda başka bir kültürel ortama giren birey, o kültürü tanıma çabası ile bir an önce o kültüre kabul edilmek için uyum gösterir ve onunla bütünleşir. Bunu o kültürü kabullenmek olarak gösterilebiliriz. Ancak, bazen daha iyi şartlara doğru göç edilen yerde bir takım sorunlar ortaya çıkabilir. Bunlardan birisi, gidilen kültürün farklılığından dolayı o kültürü benimseyememe ve dolayısıyla o kültürel yapıyı ve değerler sistemini yadırgamaktır. Göçmen çoğu zaman yeni kültüre uyum gösteremez ve yeni değerleri özümsemekte zorlanır. Kendi kültürünü korumak için göç ettiği yerdeki toplum ile kültürlerarası bir bağ kurmayı reddeder ve böylece birey ile toplum arasında ayrışma görülür (Er, 2015: 46). Kendi kültürünü küçük görüp, diğer kültürü kabullenen birey ise kültürleşme (asimilasyon) gösterir (Güvenç, 2019). Bir başka değişle, yeni kültür ve toplumla etkileşime geçerek duygu düşünce ve davranışları onlara göre şekillendirir. Marjinalleşmede ise birey ne kendi kültürünü, ne de yeni kültürü beğenir ve farklılaşmayı seçer (Yalçın, 2017: 73).

Kültürlenme modeline örnek olan bir takım etmenler, kültürlenme sürecinde de etkindir. Bunlar arasında en önemlileri sosyo-ekonomik koşullar ve kuşaklararası farktır. Genç 
göçmenler yetişkinlere göre yeni kültüre farklı yaklaşmakta ve bu nedenle kültürlenme farklı düzeylerde gerçekleşmektedir. Öyle ki, çocuklar girilen yeni ortam ve kültür ile özdeşim kurmada zorlanmazken yetişkinler zorlanabilir. Ayrıca, kültürlenme sürecini etkileyen bir başka önemli etmen, göç edilen kültürün sahiplerinin yeni gelenlere karşı gösterdiği tutumdur. Onları tanımadan önyargılara göre değerlendirebilmektedirler. Göç ile iç içe geçmiş bir başka dikkat çeken etmen ise kimlik oluşumudur. 1950'lerin başlarında ortaya atılan bu kavram 1980'lerde derinlemesine irdelenir. "Kimlik konusu salt kimlik bilgilerinden çok o kişinin algılama ve aidiyet sorunuyla yakından ilgilidir" (Boyacı, 2010). Bozkurt Güvenç'in de tanımladığı gibi kimlik, bir bireyin kendisini nasıl algıladığı, kiminle özdeşleştirdiğidir (2019: 48). Hofstede ise, çocuğun içinde büyüdüğü kültürün önemini vurgulayarak "bireyin sahip olduğu kimliğinin üzerinde, çocuğun içinde yaşadığı kültürün görünmeyen bir mührü vardır" der (2015: 438). Kimlik gelişimi kurulan sosyal ilişkilere göre şekillenecektir (Özgüzel, 2016: 240). Konuştuğu dil de o ülkenin kültürü ile sıkı bir bağlantı içindedir (Güvenç, 2019: 48). Küreselleşen dünyada göç olgusunun hiç bitmeyeceğini varsayarak, çok kültürlü ve çok uluslu devletlerde yaşamanın kaçınılmaz olduğunu kabul etmeli ve bu yapılara hoşgörü ile yaklaşmayı kolaylaştıracak politikaların inşa edilmesi hedeflenmelidir.

\section{Kırsal alandan kırsal alana ilk göç}

Romanda, anlatıcı başkişinin babası Selim Uslu uzun yıllar bekâr kaldıktan sonra otuz sekiz yaşında ilk görüşte âşık olduğu Aşme ile evlenmek için köyü Hemgin’i bırakıp onun köyü Sofyan'a yerleşerek ilk iç göçünü yapar. Burada kurgulanan çekici göç etmeni Aşme'nin ve dayısının isteğidir. Gerçekte de var olduğu gibi Selim başkasına söz verilmiş olan Aşme ile evlenebilmek için tek çareyi onu kaçırmakta bulur, ertesi gün geri götürür ve evlenmek istediğini söyler. Dayı; "Geleneğe göre yabancı adamların yanında bir gece geçirmiş olan yeğenini vermekten başka çaresi olmadığını" kabul eder ve oraya yerleşmelerini isteyerek bir başka çekici etmen sunar (Işı1k, 2014: 117). Dayısı tarafından beş yaşından beri öksüz ve yetim olarak büyütülmüş Aşme'nin de "tek akrabam” dediği dayısını bırakmak istememesi ise yine bir çekici etmendir. Orada yaşamalarını destekleyen yeni etmenlerin oluşumu ile köklenirler. Küçük bir evleri, bostanları, bahçeleri ve büyük baş hayvanları olur. Romanın baba karakteri Selim olumlu etmenler sonucunda yerleştiği Sofyan'da anlatıcı ve ezgici yeteneği ile sevilip sayılan, herkesin yardımına koşan bir komşudur. Ölen çocuklarının ardından ellerinde kalan oğulları Yusuf, Mehmet (Miran) ve kızları Elida ile ileride göçe neden olacak itici etmenler karşılarına çıkana kadar karı koca bu uzamı sahiplenerek on sekiz yıl mutlu yaşar ve göç olgusunun olumlu yanlarını deneyimler.

Aslında Aşme’nin annesi yaşamaktadır ama zorunlu bir göç, bir sürgüne zorlamış ve k1zına hasret bırakılmıştır. Aşme'nin babası öldükten sonra, 22 yaşında dul kalan Esmamperi ikinci evliliğini Sünni Gömbe köyünden olan Osman Bey ile yapar. "O dönemde Sünniler ile Aleviler arasında katı ayrışma" vardır, ona "Sen aklını mı kaçırdın be adam, Sofyan'da Sünni’ye verilecek kız daha anasının karnından doğmadı" dense da zengin toprak sahibi bunları ciddiye almaz ve onu tek akrabası olan kardeşi Hüseyin’den ister (Işık, 2014: 178). Lakin sert bir cevapla karşınca sadece Esmamperi'nin “evet” onayı ile küçük oğlunu yanına almasına müsaade etmesine rağmen onu kızından kopararak alıp götürür (Işık, 2014: 179). Gittiği Sünni köyde, Alevi olduğu için köyün kadınları tarafından çeşme başında tartaklanan 
Esmamperi, "dinsiz köpek", "pis davetsiz misafir" diye hakaretlere ve eziyetlere, eline geçirdiği bir balta ile karşı koyarak onları sindirir ve kendini kabul ettirir (Işık, 2014:180-181). Ancak, kızını ziyaret etmek için Sofyan'a geri gittiğinde sadece kızı tarafından "beni annem ölmüş" diye reddedilmez, aynı zamanda geldiğini duyan köylüleri tarafından "günahkâr orospu geri gelmiş" hakaretleri ile taşlanıp, tekme tokat öldürülesiye dövülerek kendi kültüründen dışlanır (Işık, 2014: 182). Hem itici, hem de çekici göç etmenleri nedeni ile bir daha da geri dönemez ve kızını göremez. Çekici etmen dul bir kadın daha iyi şartlar altında yaşamak için tekrar evlenmesi; itici etmen ise farklı mezhepten birisi ile evlendiği için her iki mezhebin bireyleri tarafından önyargılar nedeni ile dışlanmasıdır. Burada, küçük kızının olumsuz telkinlerden dolayı onu istememesi ise en katı itici etmendir.

\section{Kırsal alandan kırsal alana ikinci göç}

Eserde bir kaza nedeni ile Selim'e ve ailesine yeni bir iç göç doğar. Bu sefer tüm aile zorunlu ve itici bir göç etmeni ile karşı karşıya kalır. Bir komşunun duvarının yapımına yardım eden Selim'in ayağına kocaman bir taş düşer ve bacağı birkaç yerinden kırılır. Aynı zamanda köyün kırıkçı-çıkıkçısı da olan celep (kasap) Atilla'nın kasıtlı ve yanlış bağlaması sonucu bacağı kangren olur ve Muş’ta hastanede kesilir. Köyde 'topal' olarak anılmaya başlaması göç fikrini tetikleyici itici etmenlerin başında gelir. Romanın başkişi ve anlatıcısı Mehmet’e arkadaşları "Şimdi tek bacağı var öyle mi? Yani topal oldu öyle mi?" diye sorduklarında Mehmet babasına topal denmesini içine sindiremez ve onlarla dövüşür. Bu kavga arkadaşlarının onu dışlamasına ve onun köyden göç etme fikrine sıcak bakmasına neden olur (Işık, 2014: 101). Ailenin reisi Selim artık işe yaramaz bir adam haline geldiğini, saygınlığını yitirdiğini düşünerek bu durumu hazmedemez ve depresyona girerek içine kapanır (Işık, 2014: 100). Artık asık suratlı, koltuk değneklerine mahkûm, hikâye anlatma isteği yok olmuş bir adamdır; "Anlatacak bir şey kalmadı ki, her şey anlamını yitirdi... ben hiçbir şey değilim” demesi hayata küstüğünü ve bunu kendi köyü olan Hemgin'e geri dönmek için itici etmen olarak sunduğunu görürüz (Işık, 2014: 140). Eşi ayak direttiğinde çaresizce: "Lütfen Aşme, burada daha fazla kalamam... her an akl1mı yitirebilirim” diyerek göç fikrine bir başka itici etmen olarak gösterip onu ikna etmeye çal1şır (Işık, 2014: 171). Eserde yumuşak başlı olarak gösterilen ve eşinin onayı olmadan hareket etmeyen Selim, kendisi ve ailesi için itici ve çekici etmenler içeren göç sürecini başlatmak için kendi başına verdiği ani bir kararla hayvanlarını satar. Artık Sofyan’da onları bağlayan bir şey kalmamıştır ve Selim'in kasıtlı hazırladığı bu zeminde göç etmek zorunlu hale gelir.

Romanda, göç edilecek Hemgin diğer aile fertleri için itici bir etmen oluşturur. Aşme için akraba yoktur, kimi kimseyi tanımaz, hazır bağ bahçesini bırakıp kurak bir yere gidecektir. On sekiz yaşındaki büyük oğul Yusuf okumak için gönderilip gelmediği Muş’tan zorla geri getirilmiştir ama başka bir köye gitmektense tekrar şehre gitmek için can atmakta ve firsat kollamaktadır. Çünkü çekici şehir hayatını sevmiş ve orasıyla bütünleşmek istemektedir. On üç yaşındaki anlatıcı Mehmet (Miran) ise babasına destek için; "Hemgin’i görmek isterim” diyerek olumlu duygularını dile getirir (Işık, 2014: 147).

Yukarıda dile getirildiği gibi romanın aile reisi Selim var olabilmek için çekici göç etmeni olarak kendi köyü Hemgin'i görür. Anlatıcı Mehmet; "Babam köyün adını her harfi vurgulayarak tekrarladı, büyülü bir sözmüş gibi” diyerek göç olgusunun onlara zemin hazırladığını 
anlatmaya çalışır ( Iş1k, 2014: 280). Bu onun açısından bir nevi çekici bir etmendir. Orada babadan kalma büyük bir tarlası, evi ve en önemlisi ona önce babası, sonra annesi öldügünde kol kanat geren babasının arkadaşı Hemo vardır. Hemo’yu bir sığınak olarak görür. Daha sonra Hemgin'e vardığında “Burada sen varsın Hemo; sahip olduğum tek akrabamsın" diyerek ona duyduğu güvenin olumlu bir etmen olarak onu köye çektiğini açıklamış olur ( Işık, 2014: 284). Geri dönmelerine neden olan itici etmeni ona şöyle aktarır; "Hastaneden başka bir adam olarak döndüm; koltuk değnekli çekingen bir adam, çevresindekilerin acıyarak baktı̆̆ı, ailesinin sırtında kambur haline gelmiş topal bir adam" (Işık, 2014:186). İtici etmenler birbirini tetikler ve giderek yabancılaştığı Sofyan'a “ait hissetmediğini”, seyrek de olsa dışarı çıktığında yoldan geçenlerin ona bir yabancıymış gibi baktıklarını hissettiğini anlatır ve "Hayvanları satıp Sofyan'ı terk edecektim. Doğduğum köye geri gelmekten başka çarem yoktu” diyerek göç etme kararı almasına neden olan etmenleri açıklamış olur (Işık, 2014: 187).

Eserde, Selim'in kesin ve katı kararı ile aile hayvanlarının parasının tamamını alamadan eşyalarını at arabasın yükleyerek yeni mekânlarına doğru yeni bir iç göç başlatırlar. Babanın çekici etmen olarak sunduğu 'Hemgin' Aşme’nin de öngördüğü gibi kurak ve bakımsızdır. Anlatıcı Mehmet şöyle tanımlar; "Yolun iki yanındaki evlerin bizim köyümüzdekilerden daha küçük olduğunu ve daha yoksul göründüklerini fark ettim. O kadar az ağaç vardı ki bu topraklarda ne yetişir diye sordum kendi kendime. Yara bere içindeki sokak köpekleri kederli gözlerle bize bakıyor" (Işık, 2014: 183). Bu tasvir aslında romanda sonradan olacakları öncüler niteliğindedir çünkü Selim'in babadan kalma dediği toprağa el konmuş ve başkaları tarafından işlenmektedir. Köylü geldiklerinden hoşnut değildir ve onları kabullenmeyerek yeni bir göçe itmek ister. Örneğin, sokakta yaşıtlarına verdiği selamın karşılığını alamayan Mehmet orayı "çekilmez” bulduğunu ifade ederek şöyle karar alır; "Bu kederli köye, mutsuz insanlarına ve zavallı sokak köpeklerine yenilmeyecektim. Selim ve Aşme'nin oğlu Sofyan'lı Miran Uslu'yu alt edemeyecekler" (Işık, 2014: 202-203). Sonraki günlerde başlarına gelen ve itici etmen teşkil eden felaketlere bütün aile canla başla karşı koyar. Haber vermeden evlerine gelen muhtar onlara bir çeşit hesap sorar ve benimsenmediklerini vurgular:

Selim Bey siz Hemgin'den gideli kaç yıl oluyor? Yirmi yıl kadar, öyle değil mi?...Bu köye uzun yıllar önce sırtınızı döndüğünüz konusunda hemfikiriz. Hiçbir haber bırakmadan buradan ayrıldınız... Bu karışık mevzuyu görüşmek üzere benim yanıma geleceğiniz yerde yine habersiz olarak köye geri dönüyor ve insanların elinden toprağı almak istiyorsunuz. Bunun beni ne kadar şaşırttığını anlayabiliyor musunuz? ...Köyümüzde huzursuzluk yaratıyorsunuz bunu kabul edemem... Burası İstanbul değil. Burada elinizdeki kâğıt parçası sallayıp toprağın sahibi olduğunuzu söyleyemezsiniz. Burası Hemgin, burada geçerli kurallar farklı... Farkında mısınız bilmiyorum ama kimse sizi burada görmek istemiyor (Iş1k, 2014: 209-211).

Muhtar aslında köyden gitmeleri için itici bir etmen oluşturma düşüncesi ile gözdağ1 vermeye gelmiştir çünkü tarlayı işleyen kendi oğlu ve onun yandaşlarıdır. Anlaşıldığı üzere toprağa el koymuşlardır ve Uslu ailesini dışlayıp köyden kaçırmak için de farklı yöntemlere başvuracaklarını ima eder. Devletin temsilcisi olarak seçildiği köyde bir çeşit yasa dışı hareketle mülke el koyma girişiminde bulunmuştur. Selim'in olan toprak parçası 'kayıp' olma tehlikesi 
altındadır. Hâlbuki köy muhtarını devletin memuru ve köyün başı olarak tanımlayan Devlet e-mevzuat bilgi sisteminde (1924), Köy Kanunu, (madde 10- 11); “Köy muhtarının ve yapacağı işte köy muhtarıyla birlik olanlara köy işlerinde fenalıkları anlaşılırsa Devlet memuru gibi muhakeme edilirler ve ceza görürler" demektedir. Oysaki "muhtar" köyün yasalar ile belirtilmiş işlerini yürütmek için o köyde oturanlar tarafından seçileni kimsedir (TDK Güncel Sözlük, 2019). Kanunlardan anlaşıldığı gibi, muhtar kendine ve ailesine çıkar elde etmek için devlet görevine fenalık karıştırmıştır. Diğer taraftan, sakatlanmış Selim’in toprağı olmaksızın ailesini nasıl doyuracağı sorusunu duymazlıktan gelerek çözüm üreteceği yerde, köyün bir ferdinin ve ailesinin mağdur olmasına göz yumarak toprağı sahiplenebilmek için onların köyden gitmesini istemekle onları zorunlu bir göçe itmek istemektedir.

Işık'ın kurgusunda çaresiz kalan aile reisi Selim, köyde yer edinmek ve ailesini kalmaya ikna etmek için çekici etmenler aramaktadır. Eşini yanına alarak tarlasına gidip orada çalışan insanlar ile yüz yüze görüşüp iletişim kurmak ister. Niyeti "hasattan pay verme karşılığında toprağı işlemeye devam edebileceklerini” teklif etmektir çünkü toprağın büyüklüğü çekici bir etmendir (Işık, 2014: 217). Toprakta çalışmakta olan kadınlı erkekli yaklaşık on iki kişiye, babasından kendisine miras kalan bütün bu araziyi sahiplenmeye geldiğini ve tekrar kullanmak istediğini söylediğinde iletişim yerine nefret ve şiddet ile karşılar. Miras yasal bir hak olarak çekici bir etmendir ve Selim'in ailesine sunabileceği tek geçim kaynağıdır. Türk Medeni Kanunu'nun 495-501 maddeleri yasal mirasçıların, miras bırakanın kan hısımları, evlatlık ve altsoyu ile sağ kalan eşi olarak belirlemektedir. "Miras bırakanın ölümü üzerine birinci derece mirasçıları onun altsoyudur. Altsoy, miras bırakanın çocukları, torunları ve bunlardan doğanların tamamını kapsar” (2001). Köyde ailenin ekonomik olarak kazanç sağlayabileceği yer, ekip biçebilecekleri, karınlarını doyurabilecekleri tek kaynak atadan kalan bu topraktır. Ancak karşılarına çıkan en katı itici etmen muhtarın oğlu Wusar olur. Elindeki tırpanı tehditkâr bir şekilde sallayarak Selim' in tarlada hakkı kalmadığını, arazinin artık kendilerine geçtiğini hakaret ederek onları ürkütüp kaçırmak ister; "Karını ve koltuk değneklerini de al, defol git topal herif" (Işık, 2014: 230). Wusar'ın arkasında duran yaşlı Berz; “Sadece konuşmaya gelmişler, onları biraz dinlesek ne olur ki?" sözlerine; "Sen karışma” diyerek onu arkaya gönderir (Işı1k, 2014: 230). Budan sonra meydana gelen itici etmenler dehşet vericidir; duygudaşlık ve sözlü iletişim yerine kaba kuvvete başvurulur. Önce tekme tokatla Yusuf'a öldüresiye saldırıp sonra onu kurtarmaya çalışan Selim, Aşme ve Mehmet'i acımasızca döverler. Ok yaydan çıkmıştır, bir arbede yaşanmaktadır ve köylülerin niyetleri toprağı sahiplenebilmek için onları yok etmektir. Mehmet; "Wusar öfkeden kudurmuş haldeydi. Annemin beline tekme attıktan sonra iki eliyle karpuz büyüklüğünde bir kaya parçasını kaldırıp başının üstünde tuttu. Anlaşılan uçurumun dibine düşecek ilk kişi annem olacaktı" diyerek çekici etmen olarak gördükleri göçün en uç olabilecek sonucu ölüm tehlikesini aktarır (Işık, 2014: 231). Tam o anda Selim'in göç etmesinin sebebi, kurtarıcısı ve sığınağı olarak gördüğü Hemo tüfeği ile ortaya çıkar. Çekici ekonomik etmen olarak görülen toprak parçası onların sonu olma durumuna gelmiştir ama bu olay Selim'i yine de pes ettirmez. Onu hayatta tutan, elindeki en önemli çekici etmen, baba yadigârı toprak parçasından ölmeden vazgeçmeyecektir. O çocuklarını doyurabileceği tek olumlu varlığıdır.

Romanda aile fertlerinin Sofyan'a geri gitme isteklerini inatla geri çeviren Selim ölüme meydan okur gibi sadece: "Burası bizim evimiz" diyerek bu çekici etmene sıkı sıkıya tutunur (Işık, 2014: 241). Ancak yeni itici etmenler oluşur. Onları benimsemeyen Wusar ve adamları 
gece kapılarını önce yumruklar, sonra meşaleler ile dayanıp köyü terk etmezlerse evi ateşe verip onları diri diri yakacakları tehditleri savurur. Zorunlu olarak göç etmezlerse öldürüleceklerdir. O arada çekici bir etmen olarak ilk kabullenme adımı Berz adındaki ihtiyardan gelir. Evlerini ziyaret ederek toprağın onların haklı olduğunu ve Selim'in babasının köye yaptığı iyilikleri unutmadığını anlatarak; "Size kendi mahsulümün bir bölümünü vereceğim, hakkınız olduğunu düşündüğüm için” der (s. 246). Bu davranış Selim’in çabalarına 1şık olur; çabaları ilk karşılığını almıştır ve zamanla diğer köylülerin de onları kabul edeceği umudu doğar. Ancak, daha çok mücadele etmeleri gerekmektedir.

Romanın ilerleyen bölümünde ailenin köyden gitmesi için yeni itici etmenler ortaya çıkar. Su almaya giden Aşme çeşme başında bir başka dışlanma ile karşı karşıya kalır. Köylü kadınlar su almasına engel olur ve üzerine yürüyerek; "İşgalcilere suyumuzdan vermeyeceğiz” haykırışlarıyla onu köyden kovarlar (250-251). Burada bir tekrar yaşanmaktadır. Yıllar önce Aşme'nin annesinin başına Zaza-Sünni köye gelin gittiğinde çeşme başında bir kültürel dışlanma olayı gelmiştir. Burası ise bir Zaza- Alevi köyüdür ancak insanlar bir toprak parçası ve çıkarları uğruna kendi soy ve mezheplerinden olan Uslu'ları dışlamış ve ötekileştirmiştir. Tıpkı annesi gibi Aşme de pes etmez ve yıldırasıya mücadele eder ve itici göç etmenini kendi elleri ile çekici etmen haline getirir. Elindeki kova ile karşı koyar, kadınlara boyun eğdirir, onları dağıtır ve sonunda hak ettiği suyu alır. Çetin mücadelenin ardından topraklarına kavuşma umudu doğmuş gibidir. Nietzsche'nin güç üzerine kurduğu düşüncelerinde savunduğu gibi, güçlü olan ve direnen kazanacaktır (Baykan, 2000).

Romanın sonlarına doğru, Sofyan köyünde istenmeyen aile için bir başka itici etmen, doğal afet nedeniyle ortaya çıkar. Tıpkı gerçekte olduğu gibi 1966 yılının Ağustos ayında Muş depreminin öncü sarsıntıları köyde hissedilmeye başlayınca Devlet çadır gönderir. Muhtar bütün köylülere çadır dağıtıp oraya kadar koltuk değnekleri ile giden Selim’e çadır vermeyerek onu yok sayar. Bu itici etmen üzerine Aşme tek başına muhtarın kapısına gider, hakkını arayarak sonunda çadırını alır ve 'var olduklarını' kabul ettirir. Çadırın yanında bir başka olumlu etmen olan erzak vardır ve yiyecekleri neredeyse bitmiş olan ailenin imdadına yetişir. Çadır onlar için yeni bir umut doğurmuştur lakin itici etmenler henüz bitmemiştir ve gündüz "güneş çadırı firına çevirmektedir" (Işık, 2014: 257). Aşme dışında, hepsi zorla edindikleri çadırı tüm sıcaklığa rağmen dört gün daha terk etmez. Yavaş yavaş olumsuz göç etmeninin gücüne karşı koymayı öğrenmeye başlamışlardır. Ne yazık ki Wusar da pes etmemiştir ve tekrar kapıya dayanıp Selim’i dışarı çağır ve onların köyden gitmesi için ihtar vererek zorunlu bir göç etmeni yaratmak ister:

Seni son defa uyarmaya geldim. Hemgin'i terk etmeni istiyorum... sana iki gün süre...Şayet iki gün içinde gitmezseniz gelip evini ateşe vereceğiz, sonra da yanmış bedenlerinizi tek tek köyden çıkartıp atacağız...Sen hikaye anlatıcısı değil misin?...y1llar sonra doğduğu köye geri dönen adamın hikayesini bilir misin? ... Tamam, o zaman ben anlatayım. Adamın bir bacağı yokmuş (Işık, 2014: 264-265).

Okuyucuya gelecekte insanların toprak uğruna yakılarak öldürülen Selim'in acıklı hikâyesini birbirlerine anlatacaklarını ima ederek yeni bir zorunlu göç tehdidi savurmaktadır. Yazar romanında görmüş geçirmiş yaşlı Hemo’yu akil olarak göstererek Wusar'ın dış- 
layıcı şiddetine karşı koyabilmeleri için çareleri ona buldurur. Önce onlara tüfek bırakır ve sonra iri yarı bir adam olan ve silah kullanmayı iyi bilen kardeşi Nandar'dan yardım isteyerek Uslu ailesinin köyde tutunmasına yardım eder. Işık'ın sürükleyici kurgusunda itici etmenlerin sonu gelmek bilmez. Hemo'nun havaya ateş açması ile taraflar dağılır ancak Wusar bunun bedelini; "Hayatı pahasına bile olsa" ödeteceğini haykırarak aileyi bu tehditle köyden kaçırmayı hedefler (Işık, 2014: 280).

Romanda sözde devleti temsil eden muhtar bir kez daha kapılarına zorbaca dayanıp onları barbarlıkla suçlayınca Hemo ona karşı durarak: "Oğlun ve onun yandaşları fazla ileri gitti. Selim'in evini ateşe vermeye çalıştılar, yanan bir meşaleyi eve firlattılar. Elimiz kolumuz bağlı onları mı seyretseydik? Söyle bana burada barbar kim oluyor" diyerek suçun kendisinde olduğunu vurgular. (Işık, 2014: 285). Ancak, muhtar da pes etmez ve Hemo dâhil hepsinin köyden gitmesini çünkü köylülerin onları benimsenmediklerini söyleyerek onlara ayrışmayı kendilerinin yarattığını zorla kabul ettirmeye çalışır. Eserde itici etmen yerine geçen sözlü sataşmalar ve taşlamalar bol bol kullanılır.

Romanda sanki doğa da Uslu ailesini köyden atmak istemektedir ve bunu yeri sarsarak yapıp onları kaçırma niyetindedir. 18 Ağustos 1966 sabahı Mehmet annesine rüya mı gerçek mi olduğunu anlayamadığını fakat "gece yerin sallandığını" hissettiğini söyler (Işık, 2014: 289). Köydeki hayvanlarda hareketlenme başlar. Karıncaların sağa sola kaçar, köpekler hep birden havlamaya başlar, eşekler daireler çizerek anırır, keçiler huzursuzca meler ve sığırcıkların sürüler halinde kaçarcasına uçuşur (Işık, 2014: 290). Birden köye "binlerce kızgın boğa girmişçesine" yer sallanmaya başlar: onları ebediyete göç ettirmek isteyen doğa dünyanın sonunu getirmek ister gibidir (Iş1k, 2014: 290).

Gerçekte, 1966 yılında Varto'da iki deprem meydana gelir. İlki 7 Mart gecesi 03:16'da 5.6 şiddetinde gerçekleşir ve 14 hayat alır. Diğeri 19 Ağustos'ta 14:22'de, Richter ölçeğine göre 6.9 şiddetinde meydana gelir. Muş, Bingöl ve Erzurum'u da etkileyen bu afet 2394 can alır (Tarihtebugün, 2019)

İtici bir göç etmeni olan deprem romanda taş üstünde taş bırakmaz ve sadece Hemginde 60 ’tan fazla insan hayatını kaybeder. Uslu ailesine yine göç yolu görünür (s.308). Tıpkı gerçekte olduğu gibi her afette olduğu gibi devlet elini uzatır ve her bir aileye yeni bir yaşam kurmaları için bin lira verilmek üzere maddi destek gönderip muhtara dağıttırır. Uslu ailesi Hemgin'den ayrılıp büyük şehir İzmir'e doğru üç gün sürecek yolculuğa çıkarlar. Orası Ege Denizi kıyısında büyük, benzersiz, çekici ve güzel bir şehirdir; kocaman Palmiye ağaçlı, uzak diyarlara giden gemilerin demir attığı limanı olan bir şehir (Işık, 2014: 309).

\section{Kırsal alandan kente göç}

Işık, Kayıp Toprak (2014) adlı eserinde depremi ilk anda itici bir etmen olarak kurgulamış olsa da Uslu ailesine yeni bir göç nedeni sunarak onların daha iyi şartlar ve yerler bulmalarını istemektedir. Şimdi “İzmir'e” gidilecektir ve bu sefer herkesin gönüllü olduğu bir iç göç süreci başlar. Kendi özgür iradeleri ile başlattıkları bir iç göç sürecinde tren garına gidilir, tek yön biletler alınır ve İzmir trenine binilir. Duyduklarına göre büyük şehirde her şey daha güzeldir. Öyle ki İslamoğlu ve diğerleri, göç edilecek ve yerleşilmek istenen yerler 
arasındaki bilgi alışverişinin, göçü kolay kıldığını söylerken, teknolojik gelişmeler, ulaşım ve haberleşme arasında bağ kurularak göçün hızlandırdığını ekler (2013: 51). Ayrıca, günümüzde, kırsal alanda yaşayanlar, iletişim araçları ile kentsel yaşam hakkında kolay bilgi edinip gelişen ulaşım imkânları ile kırsal alandan şehre hareketliliğini artırdığını da değinir. İzmir'e vardıklarında karşılaştıkları genç taksici ailenin Muş Varto’dan geldiğini öğrenince kendisinin de oralı olduğunu söyleyerek sıcak davranır ve onların bu kente gelişini benimser. Hatta taksi ücretini dahi almaz. "Muşlu dostlardan ilk seferde para alınmaz" der (s. 332). Belirli yerlerden göç edenlerin aynı yerlere yerleşmesi, barınma, uyum sağlama ve iş bulma olanakları açısından kolaylık sağlar (Yalçın, 2017: 93-94). İlk göç edenler engelleri aştıkça daha sonra göç edecek olanların üzerinde olumlu etki bırakır ve onlar için engelleri daha kolay aşılır kılar. Uslu ailesi, koruyucu melekleri Hemo yine yardım elini uzatmış ve onlara yardım elini esirgemeyecek dostlarının adresini vermiştir. Hemo'nun adını duyan Orhan Bey onları candan karşılar, evine buyur eder ve ikramda bulunur. Büyük şehrin çekici gücü olumlu yanlarını göstermeye başlamıştır artık. Ev aradıklarını öğrenen Orhan Bey, yeni vefat etmiş teyzesinin meyve ağaçl1, güzel bahçesi olan küçük evini isterlerse "onlara kiraya verebileceğini söyler” (Işık, 2014: 333). Şanslarının döndüğünü başkahraman Mehmet şöyle aktarır: "Kötü yazgımızı nihayet geride bıraktığımızı düşündüm” (Işık, 2014: 333). Bu güzel yer, köyden kente göçün çekici gücünü kanıtlamıştır çünkü ilk gördüğünde Mehmet cennete geldiklerine düşünür. Ev eşyalıdır ve buzdolabı bile vardır. Orhan Bey anahtarı evin hanımı Aşme’ye teslim edip gider. Yusuf ve Mehmet kısa sürede iş bulur ve evin geçimini üstlenirler. Selim de iş aramaya çalışır ancak bulamaz ve kahvehanede takılmaya başlar. Tekrar anlatıcı yeteneğini ele almış kısıtlı Türkçesi ile hemşerilerine memleket hikâyeleri anlatarak kısa sürede herkes tarafından sevilir. Hikâyelerinin karşılığında bedava çay ve yiyecek ikramı alır. Ne yazık ki olumlu yönleri ile onları kendine çeken İzmir'in kötü yönleri de vardır. Yusuf daha önce Muş’ta olduğu gibi şehir hayatının karanlık yüzü tarafından burada da baştan çıkarılır. Muş’ta edindiği içki alışkanlığına geri döner, yine ailesinden uzaklaşır, işinden de uzaklaşınca ayrışmaya başlar. Artık ne Mehmet'in öykündüğü ağabey modelidir, ne de babanın özlemini duyduğu iyi okumuş ve iyi meslek edinmiş şehirli delikanlı. Ailenin örnek evladı gitmiş yerin ayyaş bir serseri gelmiştir.

Romanda şehir hayatının sunduğu çekici ekonomik etmen sayesinde Yusuf önce bir lokantada işi bulur ve ailenin geçimini üstlenir. Mehmet ise pazarda bir zerzevatçının yanında işe girer. Her şey yoluna girmiş gibidir ve babanın tekrarladığı gibi "her şey güzel olacaktır" (Işık, 2014: 334). Patronu onu sever, öğlen yemekleri ısmarlar. Mehmet kalabalık ve şehir hayatından etkilenmiştir etrafını pür dikkat izler anlamadığı şeyleri sormaktan ve öğrenmekten çekilmez. Örneğin, cami minaresinde okunan ezanı ilk olarak duyduğunda, annesine neden kendi köylerinde ezan okunmadığını sorunca annesi kültürel farklılığa şöyle açıklık getirir: "Sünniler Camiye gider, biz Aleviler için Cem vardır” (Işık, 319). İzmir'de kocaman mavi bir deniz vardır ve özgürlük kokuyordur. 1960'larda köyden kente göç eden insanlar imkânları dâhilinde gecekondu yapıp otururlar, ancak romanda Uslu ailesinin böyle bir imkânı yoktur. Yazar onları gecekondu mahallesine yönlendirmez. Onları güzel günler beklemektedir ve göçün çekici gücünün etkileri devreye girmiştir. Mehmet defterine: "Küçük evde geçirdiğimiz ilk günler rüya gibiydi” diye yazar (352). Ancak göçün bir başka itici etmeni olan özlem duygusu onun peşini bırakmaz ve Sofyan'da kalan arkadaşlarını özler. Bir gün defterine şöyle yazar: “Ali’yi görmek 
için Sofyan’a geri gideceğim” (353). Ali ile dostluğunun sonsuza kadar süreceğini hayal eder. Göçlerin en ağır sonuçları arkada bırakılan arkadaşlar ve ailelere duyulan bu özlemdir ve Mehmet arkadaşına duyduğu özlemi defterine yazarak somutlaştırılır.

Eserde Yusuf'un sürekli olarak iş bulması Aşme ve aile için güvencedir çünkü evin kirasını düzenli ödeyebileceklerdir. Yusuf önceleri muntazam olarak annesine verdiği aylığını vermeyi bırakır. Parayla düzgün elbiseler alarak şehir yaşamına özgü giyinmeye çalışır. Kentlileşmede güzel ve güne uygun kıyafetler kültürleşme açısından önemlidir (Şen, 2015: 250). Yusuf da güzel giyinerek şehirli giyim tarzını taklit eder ve şehirli gibi görünmek ister.

Yukarıda romanda örneklemeye çalıştığımız ikinci köy Sofyan'dan İzmir'e yapılan göçün kişiler açısından itici ve çekici etmenlerini ve sonuçlarını Tablo 1'deki gibi gösterebiliriz:

\begin{tabular}{|l|l|l|l|}
\hline Kişiler & İtici etmenler (köy) & Çekici etmenler (şehir) & Sonuç \\
\hline Mehmet & Zorunlu göç, deprem & $\begin{array}{l}\text { Babasının mutluluğu, } \\
\text { Deniz, palmiyeler }\end{array}$ & $\begin{array}{l}\text { Babanın mutluluğu, iş, } \\
\text { bolluk }\end{array}$ \\
\hline Selim & $\begin{array}{l}\text { Kaza, bacağının } \\
\text { kesilmesi, yokluk }\end{array}$ & Miras toprak, Hemo & Refah, umut \\
\hline Aşme & $\begin{array}{l}\text { Kaza, eşinin ruh hali, } \\
\text { yokluk }\end{array}$ & $\begin{array}{l}\text { İzmir, büyük şehir, } \\
\text { palmiyeler }\end{array}$ & Konforlu bir ev, Refah \\
\hline Yusuf & $\begin{array}{l}\text { Çobanlık, köy hayatı, } \\
\text { kaza }\end{array}$ & Büyük şehir & I̧ş, Alkol \\
\hline Elida & Zorunlu göç, deprem & Aile & Aile \\
\hline
\end{tabular}

Tablo 1. Kişilere göre Çekici ve İtici Göç Etmenleri ve Sonuçları

Daha çocuk olduğu için babasına karşı gelmeyen ve zorunlu göçe boyun eğen romanın anlatıcısı ve başkahramanı Mehmet daha güzel günler göreceklerini söyleyen babasına inanır ve güvenir. Babası ile arasında özel bir bağ vardır ve romanın sonunda bunu iyice hissederiz. Örneğin, kendi kazandığı parayla babasını gezmeye çıkarır, ona yemek ısmarlar. Birlikte ilk defa midye yerler. Babasının: "Teşekkür ederim oğlum, ilk midyeyi bana kimin aldığını hiçbir zaman unutmayacağım” sözleri unutmayacak özel bir anının yansımasıdır (Işık, 2014: 356).

\section{Eğitim yolu ile kültürlenme}

Işık romanında çocukların ailelerinin aldıkları göç kararları nedeniyle yaşadıkları psikolojik zorluklara ve kazanımlara da değinir. Roman anlatıcısı Mehmet yaşı küçük olduğu için babasının isteğinden dolayı zorunlu göçe maruz kalır, bilmediği ve hiç arkadaşının olmadığı yerlere gider. Bunları sırf babası istiyor diye boyun eğer. Babasına olan sevgisi, bağı ve hayranlığı nedeniyle ona ağabeyi ve annesi gibi isyan etmez, babasını rol model olarak alır. Hayâli büyüyünce onun gibi iyi bir çoban ve iyi bir hikâye anlatıcısı olmaktır. Baba Selim'in ise oğulları için farklı planları vardır. 
Eserde, Sofyan'da muhtar ve Muş'a okumak için gönderilen belli başlı çocuklar dışında kimse Türkçe bilmez. Romanın başında anne ve baba Sofyan'da okul olmadığı için büyük oğulları Yusuf'u kültürlenmesi için Muş’ta bir okula göndermeye karar verir. Mehmet o günleri şöyle anımsar; "Babam oğullarının cahil çoban olmalarını istemiyordu” (Işık, 2014: 23). Romanda baba karakteri köyden şehre gidip okuyan ve meslek sahibi olarak kendilerini köyün zor ve fakir şartlarından kurtaran çocukların anne ve babalarının 'okuyup kendini kurtarsın' düşüncelerine tekrar tekrar gönderme yaparak Türkiye' de kırdan kente yapılan göç eyleminin en önemli çekici etmenini vurgular.

Mehmet on yaşındayken Ankara'dan köye öğretmen tayin edilir. Öğretmen sekiz yaş üstü çocukların kanunen okula gönderilmesi gerektiğini vurgulayınca Selim Mehmet'i okula göndermeye karar verir. "Evde ve köyde Zazaca konuşuluyordu” diye aktaran Mehmet, babasına neden Türkçe öğrenmesi gerektiğini sorduğunda; "ülkenin geri kalan yerlerinde Türkçe konuşulduğu için" ve "kim bilir, belki bir gün doktor olmak ya da başka önemli bir görev için büyük şehre gidersin...o zaman bu dili bilmen gerekir” yanıtını alır (29). Öğretmen köyde kaldığı bir buçuk yıl boyunca çocuklara okuma- yazma öğretir. Azmi ve derslere olan ilgisi Mehmet'i çalışkan bir öğrenci yapar ve Türkçe kelimeler öğrendikçe onları benimseyerek anne ve babasına onlarla hitap etmeye başlar. Öğretmen çocuklara Küçük Mehmet adında bir çocuk kitapları serisini dağıttıkça Mehmet bu kitapları okur ve kendini hikâyedeki Mehmet ile özdeşleştirir. Yazar burada kitaba çekici bir etmen niteliği yüklemiştir ve Mehmet'in sonradan büyük şehre yapacağı göçe gönderme yaparak daha önceden okuma-yazma ve Türkçe öğrendiğinden dolayı bu kültüre kolay uyum sağlayacağını öncülemektedir.

Romanın sonlarına doğru İzmir'e göç ettiklerinde, bir kırtasiye dükkânının vitrininde tesadüfen öğretmeninin ona okuttuğu Küçük Mehmet serisinin Küçük Mehmet Şehirde kitabını gören Mehmet maaşından biriktirdiği parayla bu kitabı alır (346). Bu son kitap onun ait olduğu yere geldiğini onaylar nitelikte karşısına çıkmıştır. Kitabın serisi tamamlanmış ve tüm seriyi okumuş olan Mehmet gelişimini tamamlamış gibidir. Şehre ilk olarak on üç yaşındaki gelmiş olmasına rağmen okuyucu onun şehir hayatını ne kadar çabuk benimsediğini ve para kazanmanın ona hissettirdiği özgüven ve özgürlüğü görür. Yazar ergenlik yaşına gelmiş bir çocuğun çalışarak kendi kazancını elde etmesinin ona güven katarak olgunlaştırdığını göstermektedir. Bir gün kendi kazandığı para ile babasını şehirde gezmeye çıkaran Mehmet'e babası şehrin çekici gücünün sunduğu imkânları; okuyarak doktor ya da avukat olabileceğini örnekleyerek ondan beklentilerini anlatır. Gerçekte, bu şartlar altında Mehmet' in okuması iyi bir meslek sahibi olması hayâl ötesidir. Bunu idrak etmiş olan Mehmet babasının güvenini sarsmak istemeyerek karşı gelmez ve okuyacağına söz verir. Baba ise hayallerini ve nedenlerini şöyle açıklar: " $\mathrm{Bu}$ hayatta bu yabancı şehirde ne yapacağımı bilmiyorum ama oğlum bütün bunlara rağmen ümitliyim. Gelecekten ümitliyim. Neden biliyor musun?” diye sorar ve şöyle devam eder; "Sana inandığım için, sen benim ümidimsin. Sen benim hiçbir zaman sahip olamadığım ama şehrin sana sunduğu olanaklardan yararlanacaksın. Çok çalışacaksın ve bir yerlere geleceksin çünkü sahip olduğun her şeyi kaybetmenin ne demek olduğunu biliyorsun” (356). Okuyucunun anlayacağı gibi babasının Mehmet’ten beklentisi yüksektir. Oysaki Mehmet on üç yaşındadır ve köydeki ilkokulda sadece bir buçuk yıl okumuştur. Bu eğitimle nasıl doktor ya da avukat olacaktır? Babasını çok seven ve incitmek istemeyen her çocuk gibi ona her zaman çok çalışacağına söz verir. Ancak iyi bir yere gelmek için elinden geleni yapacağını söyleyince babası 
birden; "Oğlum bize bakma sırası şimdi sende" diyerek onun omuzlarına büyük bir sorumluluk yükler (357). Silkinip başının çaresine bakması gerekmektedir çünkü uzun yıllar onları takip eden lanetten kurtulmaya çabalama sırası artık ona geçmiştir. Uçsuz bucaksız ve eşsiz denizi ile göçmenlere her zaman umut vaat etmiş olan İzmir kurguda da bu umudu devam ettirir. Yazarın altın gibi betimlediği palmiyeleri ise şehirde para kazanarak zengin olma ihtimallerine gönderme yapmaktadır. Bilindiği gibi köylerde İzmir ve İstanbul gibi büyük şehirler tasvir edilirken şehrin taşı toprağı altın betimlemesi kullanılarak kırdan kente göç edenlerin mutlaka iş bulup çalışacağı ve zengin olacağı düşüncesi yaygındır.

Işık ile yapılan mülakat ve söyleşiler aracılığıyla büyüklerinin öz yaşam öyküsünden izler taşıyan Kayıp Toprak'ta yerine getirilemese bile ailesinin göç ettiği Hollanda'da ikinci nesli temsil eden yazarın romanda vurgulanan vaatleri kendisinin yerine getirerek başarılı bir eğitim hayatından sonra avukat olduğunu öğreniriz. Dahası, yazarın bu romanı kurgulayarak, dedesinden kendisine geçen genlerinde taşıdığı anlatıcı mirasını kullanarak ödüller alan bir hikâye anlatıcısı ve roman yazarı olması, roman karakteri Selim'in ve de başkarakter Mehmet'in hayallerinin gerçekleştiğini gösterir.

\section{Sonuç}

Hollanda dilinde yazılan Kayıp Toprak romanı Hollanda kamuoyunda büyük ilgi görür ve hem Hollandalı hem de Belçikalı Flaman okurlar ve eleştirmenler tarafından ödüle layık görülür. Murat Işık gerek yazdığı öykü ve romanlar gerekse yaptığı söyleşilerle iki kültür arasında ayrımcılığın değil bütünleştiriciliğin, ötekileştiriciliğin değil kaynaştırıcılığın temsilcisi olur. Bu romanın konusu Zaza/Alevi/Türk kültürlerini Flaman okuyucusuna tanıtarak bu kültürlere karşı farkındalık oluşmasına ve orada yaşayan Türkiyeli göçmenlerin kültürü ile Flaman kültürü arasında iletişime büyük katkıda bulunur. Romanın konusu Türkiye topraklarında geçtiği ve kırsal alanda yaşayan yoksul ailelerin yaşam mücadelesine ve göç etme nedenlerine değindiği için Türk edebiyatını da ilgilendirmektedir. Türkiye dışında üretilen Göçmen Edebiyatı Türk kamuoyunun da ilgisini çekmektedir ve ilgi gören edebi nitelikteki eserler Türkçeye çevrilerek Türk okuyucuyla buluşturulmaktadır. Kırsal ve kentsel uzamlarda yaşananlara koşut olarak itici ve çekici etmenlerin rol oynadığı Kayıp Toprak romanı ülkemizde halen yaşanan iç göç olgusuna da 1şık tutabilecek özelliklere sahiptir.

Ayrıca, kendisini ateist olarak tanımlayan yazar romanında gerçekçi ve tarafsız bir bakış açısı ile kırsal alanda yaşanan Alevilik ve Sünnilik çatışmasına değinerek kırsal alanda yaşayan Zazaların mezhep farlılıkları nedeni ile birbirlerini dışlayarak ötekileştirdiğini gösterir.

Zaza/Alevi kökenli Hollanda vatandaşı yazar Murat Işık romanında olayları başkişi ve anlatıcı Mehmet'in gözünden önce Sofyan köyünden Hemgin köyüne, sonra da İzmir'e göçe neden olan itici ve çekici etmenler eşliğinde anlatır. İtici etmen olarak baş gösteren elim bir kaza sonucu göç etmek zorunda olduğunu hisseden baba, anne, küçük kızları ve oğulları Yusuf ve Mehmet'in karşı karşıya kaldıkları diğer sorunlar, kültürlenme süreci, kırda karşılaştıkları sömürülme, dişlama ve ötekileştirmedir. Çekici etmen olarak görülen toprak parçası, koruyucu kişi Hemo, daha iyi yaşam şartları ve iş imkânı sunan büyük şehir, kazanımlar, hayal kırıklıkları, pişmanlıklar, sevinçler ve daha iyi şartlar için verilen tavizlerle birlikte inceden inceye anlatır. Göç, ekonomik, sosyal, coğrafi nedenlerle şu ya da bu şekilde Uslu'ları ait oldukları topraklardan sökerek başka mekânlara ve beraberinde başka kültürlere, başka dile ve bambaş- 
ka bir sosyal çevreye savurur benliklerinde derin izler bırakır. Ailenin her bir bireyi için farklı bir süreç işler; kırdan kıra ve kırdan büyük şehre göçleri bağlamında her biri farklı bir kültürlenme sürecinden geçer. Her birey bulunduğu gerçeklik içinde kendisini yeniden var etmeye çalışır. Kır, kent ve diller arasında savrulan bireyler durumu psikolojik olarak sindirmeye çalışarak kendilerine yeni bir aidiyet yaratma çabasındadır. Başkarakter Mehmet öğretmeninin ona verdiği ismi benimsediği gibi ekonomik özgürlüğü tadınca kendini yeniden var etmek için şehir hayatına kolaylıkla ayak uydurarak yeni kimliğini daha kolay benimser. Ailenin iki kadın üyesi anne Aşme ve küçük Elida'nın duyguları hakkında fazla bilgi olmamasına rağmen, her ikisinin buzdolaplı yeni evlerini ve bolluk simgesi olan nar ve limon ağaçlarıyla dolu bahçelerini çok sevdiklerine şahit oluruz. Baba Selim ve ağabey Yusuf'un yeni uzama ayak uydurma süreci engebelidir çünkü karşılarına işsizlik ve alkol gibi engeller çıkar.

Hollanda basının sersemletici 'güzellikte' bir aile öyküsü olarak tanımladığı Murat Işık’ın öznel yaşantısına dayanan Kayıp Toprak'ta iç göçün izlerini sürmek mümkündür. Yazarın ailesinin de göç etmesine neden olan itici ve çekici göç etmenleri birer motif olarak karşımıza çıkar. Anlatıcı Mehmet Uslu ve ailesinin babanın hayalini kurduğu 'güzel günlere' ulaşmak için karşılarında sürmeleri gereken bir izlek vardır. Hem Işık ailesi hem de kurgulanan Uslu ailesi refaha kavuşmak için göçün zor yollarından geçerler ve kendilerine iyi yaşam şartları sunan büyük şehir İzmir'e ulaşır ve oranın kültürüne ayak uydurarak, dilini öğrenip konuşmaya başlar, bu sayede halkı ile kaynaşır ve bütünleşir.

\section{Notlar}

1 Bu gazete ve TV programının dili Hollandaca olup bu makalede kullanılmak üzere makale yazarı tarafından Türkçeye çevrilmiştir.

2 Yazarın Wees Onzichtbaar adlı ikinci eseri henüz Türkçeye çevrilmediği için buradaki çeviri makale yazarı tarafından yapılmıştır.

3 Makale yazarı Hollanda'da büyümüş ve ikinci anadili Hollandaca olduğundan eserin aslı ile Gül Özlen tarafından yapılmış çevirisini karşılaştırarak değerlendirmiştir.

\section{Kaynaklar}

Ataseven, F. (2015). Türkiye'den Avrupa'ya göç ve göçmenlerin ürettikleri metinler. [Migration from Turkey into Europe and texts produced by migrants], Göç Dergisi, Transnational London, UK, S. 2(1), ss. 59 - 68, May.

Boyacı, İ. (2010), Pazarkaya örneğinde göçmen Türk aydınının kimlik problemi ve bu problemin çözümü. Turkish Studies International Periodical for the Languages, Literature and History of Turkish or Turkic; 5(2): 878-896.

Er, A. (2015). İtici ve çekici faktörler bağlamında iç göç: Gaye Hiçyllmaz'dan firtınaya karşı. Göç Dergisi, S. 2(1), ss. 43-58.

Gürsoy, Ş. (2007). Küreselleşme ulus-devlet ve din. Dini Araştırmalar, S. 17 (2978211; 308).

Güvenç, B. (2019). Kültürün abc'si. İstanbul: Yap1 Kredi.

Hofstede, G. (2015). Allemaal andersdenkenden, omgaan met cultuurverschillen. Amsterdam/Antwerpen: Business Contact.

Işı1k, M. (2012). Verloren grond. Amsterdam: Ambo/Anthos.

Işık, M. (2014). Kayıp toprak. G. Özlen (Çev.). İstanbul: Koton. 
Özgüzel. S. (2019). Suriyeli göçmenlerin entegrasyonunda eğitim ve kültürlerarası iletişimin önemi; Hollanda örneğinden çıkarılacak sonuçlar. E-Kurgu: Anadolu Üniversitesi İletişim Bilimleri Fakültesi Uluslararası Hakemli Dergisi, (27. Cilt). S. 2, ss. 236 - 246. ISSN-1309-3487.

Said, E. W. (2006). Şarkiyatçı1ık, B. Ülner (Çev.). İstanbul: Metis.

Topçu, H. (2009). Avrupa ve Amerika'da Türk edebiyatı. Turkish Studies. 4 /1-I Winter 2009.

\section{Elektronik kaynaklar}

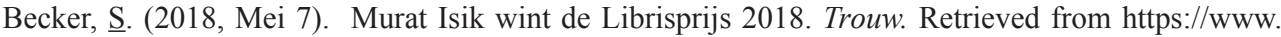
trouw.nl/cultuur-media/murat-isik-wint-de-librisprijs-2018 be3034a8/?referer=https $\% 3 \mathrm{~A} \% 2 \mathrm{~F} \% 2$ Fwww.google.com\%2F.

Es, M., Ateş. H. (2010). Kent yönetimi, kentlileşme ve göç: Sorunlar ve çözüm önerileri. Journal of Social Policy Conferences, S. (48). Retrieved from https://dergipark.org.tr/tr/pub/iusskd/ issue/890/9892.

Berry, W. J. (1997) Immigration, acculturation, and adaptation. Applied Psychology: An International Review, 46, (1), 5-68. doi.org/10.1111/j.1464-0597.1997.tb01087.x.

Köy Kanunu. (1924, 7 Nisan). Resmi Gazete (S.68) Erişim adresi: http://www.mevzuat.gov.tr/ MevzuatMetin/1.3.442.pdf

Muhtar. (1 Ekim, 2019). Türk Dil Kurumu güncel Türkçe sözlük içinde. Erişim adresi: http://tdk.gov. tr/?option=com_gts

Lee, E. S. (1966). A theory of migration. Demography, S. 3(1), ss. 47-57. Retrieved from http://www. jstor.org/stable/2060063.

İslamoğlu, E , Yıldırımalp, S , Benli, A . (2014). Türkiye'de tersine göç ve tersine göçü teşvik eden uygulamalar: İstanbul İli Örneği. Sakarya İktisat Dergisi, S. 3 (1), ss. 68-93. İndirlme: https:// dergipark.org.tr/en/pub/sid/issue/30095/324728.

Parmando 24 Culture. (2015, May 24). Murat Isik: Verloren grond. Retrieved from: https://www. youtube.com/watch? $\mathrm{v}=$ MZkHRK3xjic

Piché V. (2013). Contemporary migration theories as reflected in their founding texts (trans. Catriona Dutreuilh) Population 1, (68). DOI: 10.3917/popu.1301.0153. Retrieved from: https://www.cairnint.info/article-E_POPU_1301_0153--contemporary-migration-theories-as-refle.htm.

Tarihte Bugün. (1 Ekim, 2019). 19 A ğustos 1966 - Erzurum Muş Bingöl Varto depremi. https://www. tarihtebugun.org/16619-19-agustos-1966_erzurum_mus_bingol_varto_depremi.html

Türk Medeni Kanunu. (2001, 8 Aralık). Resmi Gazete (S. 24607). Erişim adresi: https://www.mevzuat. gov.tr/MevzuatMetin/1.5.4721.pdf

Vuijsje, R. (2018, April 30). Schrijver Murat Isik: Op School Noemden ze me Schoonmaker; dat werd mijn naam. Volkskrant. https://www.volkskrant.nl/mensen/schrijver-murat-isik-op-schoolnoemden-ze-me-schoonmaker-dat-werd-mijn-naam b3f6db4f/?referer=https\%3A\%2F\%2Fwww. google.com $\% 2 \mathrm{~F} 30$

Wiegman, M. (2018, June 16). Schrijver Murat Isik: Niemand zal mij meer onderschatten .Het Parool.https://www.parool.nl/kunst-media/schrijver-murat-isik-niemand-zal-mij-meeronderschatten $\sim \mathrm{b} 121 \mathrm{c} 6 \mathrm{dc} /$

Yılmaz, C. (2011). Türkiye'de kırdan kente göç sürecinde etkili olan faktörlerden biri; evlilik yoluyla göç. Doğu Coğrafya Dergisi, S. 14 (21), ss. 221-232. İndirilme: https://dergipark.org.tr/en/pub/ ataunided/issue/2436/31184.

Yazıcı, M. (2015). Aleviliğe etnik yaklaşımlar: Zazalar - Alevilik ilişkisi II. Uluslararası Zaza Tarihi ve Kültürü Sempozyumu gec3a7mic59ften-gc3bcnc3bcmc3bcze-alevilik-sempozyumu-2-cilt.pdf: 408-425. 